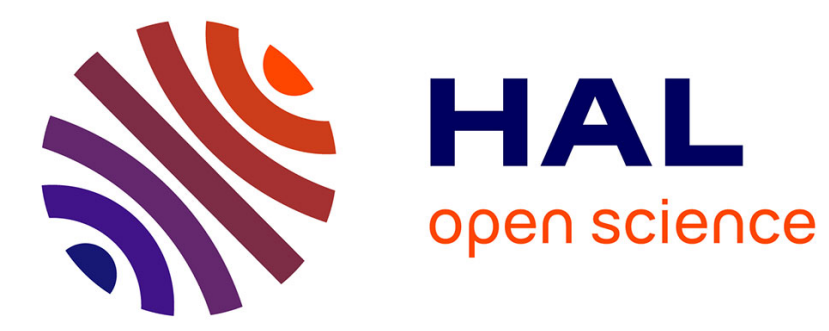

\title{
Application of nutrigenomics in eye health.
}

Cécile Delcourt

\section{To cite this version:}

Cécile Delcourt. Application of nutrigenomics in eye health.. Forum of Nutrition, 2007, 60, pp.168-75. 10.1159/0000107176 . inserm-00185027

\section{HAL Id: inserm-00185027 https://www.hal.inserm.fr/inserm-00185027}

Submitted on 10 Nov 2009

HAL is a multi-disciplinary open access archive for the deposit and dissemination of scientific research documents, whether they are published or not. The documents may come from teaching and research institutions in France or abroad, or from public or private research centers.
L'archive ouverte pluridisciplinaire HAL, est destinée au dépôt et à la diffusion de documents scientifiques de niveau recherche, publiés ou non, émanant des établissements d'enseignement et de recherche français ou étrangers, des laboratoires publics ou privés. 


\section{Application of Nutrigenomics in Eye Health}

\section{Cécile Delcourt}

Inserm U593 “Epidemiology, Public Health and Development”, Bordeaux, France; Université Victor Segalen Bordeaux 2, Bordeaux, France.

Running title : Nutrigenomics in eye health

Corresponding author : Cécile Delcourt, Inserm U593, Université Victor Segalen Bordeaux 2, 146 rue Léo Saignat, 33076 Bordeaux Cedex, France. Tel : + 33557571596 ; Fax : +33 5 57571486 ; email : Cecile.Delcourt@ isped.u-bordeaux2.fr 


\section{ABSTRACT :}

This paper reviews recent findings on the implication of nutritional and genetic factors in agerelated eye diseases: age-related macular degeneration (AMD, a degenerative disease of the retina) and cataract (opacification of the lens).

Because of direct exposure to light, the eye is particularly sensitive to oxidative stress. Antioxidants, such as vitamin E, C or zinc clearly have a protective effect in AMD and probably in cataract. In addition, two carotenoids, lutein and zeaxanthin may play a more specific role in the eye: they accumulate in the retina, where they form the macular pigment, and in the lens. Their role is probably to filter out phototoxic blue light and to quench singlet oxygen. Finally, docosahexaenoic acid (DHA, an $\omega-3$ polyunsaturated fatty acid) is particularly important for the retina, where it exerts structural, functional and protective actions.

Besides, these diseases are strongly influenced by genetics, as demonstrated by familial and twin studies. The apolipoliprotein E4 allele is associated with a reduced risk of AMD, while an association of AMD with Complement Factor $\mathrm{H}$ polymorphism has recently been demonstrated.

Nutrigenomics, by studying the interactions between genetic variability and nutritional factors represent a new challenge in order to account for interindividual variations in disease susceptibility. Such potential interactions are presented. 
There is growing evidence for major implication of nutrition and genetics in the aetiology of age-related eye diseases (age-related macular degeneration (AMD), cataract and glaucoma), which are the major causes of blindness worldwide [1]. However, the interest in nutritional risk factors for these diseases and the identification of the associated genes is still recent. As such, the interactions between nutritional and genetic factors have not yet been studied. Some hypotheses can be drawn from the known interactions between nutrition and specific biological mechanisms.

AMD is a degeneration of the central retina, known as the macula. It is associated with extracellular deposits forming yellow spots on the retina, named drusen. These deposits are probably related to decreased degradation and elimination of cellular components during the process of renewal of the photoreceptors. Late-stage AMD is characterized by the development of choroidal neovascularization (exsudative AMD) or by the disappearance of photoreceptors and underlying retinal pigment epithelium (atrophic AMD). Cataract is an opacification of the lens, which focuses the light on the retina. Glaucoma is a neuropathy of the optic nerve, leading to gradual loss of peripheric visual field and leading finally to total blindness. The prevalence of these diseases increases sharply with age. They are multifactorial, with both genetic and environmental factors. Some risk factors have been clearly identified, such as apolipoprotein E, Complement Factor $\mathrm{H}$ polymorphisms and smoking for AMD ; light exposure, smoking, diabetes and oral corticosteroid use for cataract; and intraocular pressure (IOP) for glaucoma.

Oxidative stress plays an important role in eye ageing. The retina is particularly susceptible to oxidative stress because, on the one hand, of its high content of easily peroxidizable long- 
chain polyunsaturated fatty acids (PUFA), in particular docosahexaenoic acid (DHA, an $\omega-3$ PUFA) [2]. Its susceptibility is also due, on the other hand, to the high level of in-site ROS production, due in particular to light exposure and high metabolic activity [2]. Opacification of the lens is due to oxidation of the structural proteins of the lens, inducing their aggregation [3].

Three types of nutritional factors offer or may offer protection against eye ageing: antioxidants, such as vitamin $\mathrm{C}$ and $\mathrm{E}$ or zinc; lutein and zeaxanthin, two carotenoids which accumulate specifically in the retina and lens; $\omega-3$ PUFA, and in particular DHA, which have important structural and protective functions in the retina. Initial epidemiological observations, showing that high vitamin E plasma levels may protect against AMD [4], have been confirmed by a large randomised clinical trial performed in the United States. In this study, performed on nearly 5,000 subjects, supplementation for 6 years with high doses of antioxidants (vitamin E, C and beta-carotene) and zinc significantly reduced by $34 \%$ the risk of developing advanced AMD in subjects with early AMD [5]. In parallel, numerous studies have evidenced a $20 \%$ to $50 \%$ reduction of the risk for nuclear cataract (one of the subtypes of cataract, based on the localization of the opacities) in subjects with high dietary intakes or high plasma concentrations of vitamin $\mathrm{C}$ and vitamin $\mathrm{E}$ [6]. However, in several large randomized clinical trials, the risk for cataract was not reduced with antioxidant supplementation [7-9]. Only the REACT study showed an effect of supplementation with vitamin C, E and beta-carotene on cortical cataract [10]

A more recent research domain regards the role of two carotenoids, lutein and zeaxanthin, for the protection of the retina and the lens. These carotenoids accumulate in the macula, where they are known as the macular pigment [11], and they are also the only carotenoids found in the lens [12]. Besides their anti-oxidant properties, they probably act as a filter against the 
phototoxic effects of blue light [11]. Two clinical studies have shown that eyes at risk of AMD have lower density of the macular pigment $[13,14]$. Epidemiological studies also suggest that a high intake or high plasma levels of lutein and zeaxanthin could protect against AMD and cataract [15-22]. Although all these studies have yielded results in the direction of a protective effect, they were not always significant due to small sample sizes. A small randomized study showed improvement of near visual acuity with lutein supplementation, in subjects with atrophic AMD [23].

Finally, DHA is a major component of the photoreceptors, where it exerts structural (membrane fluidity, interaction with rhodopsin) and protective functions [24]. The protective functions include the systemic anti-inflammatory, anti-angiogenic and anti-apoptotic functions, but also specific actions such as increase in lysosomial acid lipase, leading to increased lipid degradation in the retinal pigment epithelium [24]. Few epidemiological studies are available concerning the associations of AMD with fat. In two cross-sectional studies $[25,26]$, weekly fish consumption, which is the main source of DHA, was associated with a 50 to $60 \%$ reduction in risk for AMD, after multivariate adjustment. In the Eye Disease Case Control Study, a high dietary intake of $\omega 6$ PUFA was significantly associated with a 2 fold increased risk for exsudative AMD, after multivariate adjustment. Consumption of $\omega 3$ PUFA was significantly associated with a $31 \%$ reduction in risk for AMD after age and gender adjustment, but not after multivariate adjustment. Results were similar for fish intake [27]. In a pooled analysis of the Nurses' Health and Health Professionals' cohort studies, subjects consuming fish had a reduced risk of developing AMD, after multivariate adjustment [28]. High DHA intakes were also associated with a reduced risk of AMD, whereas, surprisingly, high intakes in alpha-linolenic acid were associated with an increased risk. Finally, in a study on 261 patients, initially presenting early AMD, total fat intake, and more specifically, intakes of vegetable fat, MUFA and PUFA (mainly due to $\omega 6$ 
PUFA) were positively associated with the risk of developing late AMD [29]. Fish intake was associated with a decreased risk of late AMD only in those with a low dietary intake of linoleic acid. Globally, these results suggest that excessive intake of $\omega-6$ PUFA, and low intake of $\omega-3$ PUFA may be associated with increased risk for AMD. Recent studies suggest that $\omega-3$ and $\omega-6$ PUFA may also be implicated in other eye conditions, such as glaucoma [30] or dry eye syndrome [31].

Beside the nutritional dimension of AMD and cataract, these diseases are strongly influenced by genetics, as demonstrated by familial and twin studies [32-37]. The apolipoliprotein E4 allele is associated with a 50\% reduced risk of AMD [38-43]. Recently, three independent teams simultaneously demonstrated a significant association between the $\mathrm{Y} 402 \mathrm{H}$ polymorphism of the complement factor $\mathrm{H}(\mathrm{CFH})$ gene and AMD in North American subjects [44-46], immediately followed by three other corroborating papers in North American populations [47-49], one study from France [50] and one from Iceland [51]. Y402H is a common variant, with about $30 \%$ of the general populations bearing the minor (C) allele (at least in Caucasians). In these studies, subjects heterozygotes for $\mathrm{C}$ have a 2.5 to 4 fold increased risk for AMD, while subjects homozygotes for $\mathrm{C}$ have a 3.5 to 7.5 - fold increased risk for AMD [50]. Complement Factor $\mathrm{H}$ is a key regulator of the complement system of innate immunity [52]. Histologic observations are consistent with inappropriate activation of the complement system in AMD [53].

Finally, several linkage studies show an association of AMD with chromosome 10p26 [54]. With respect to cataract, a recent linkage study identified a major locus on chromosome $6 \mathrm{p} 12$ q12 for cortical cataract [55] 
Interactions between genetic variability and nutritional factors represent a new challenge in order to account for interindividual variations in disease susceptibility. While some properties of nutritional factors rely on direct effects (such as antioxidant properties, or structural functions of DHA), many nutritional factors also have cellular effects and interact with genes. Nutrigenomics in eye health therefore potentially include all genes implicated in the metabolism or activities of nutritional factors associated with eye diseases, and all nutrients implicated in the activities of genes associated with eye diseases, thereby opening a vast research domain. Since the genes identified to date are from the lipid metabolism (apolipoprotein E) and innate immunity (Complement Factor H), interactions with lipids and antioxidants are particularly expected. Recently, in an animal model, combination of the apoE4 allele with high-fat diet induced modifications of the retina that mimic the pathology associated with human AMD [56]. It is also well known that PUFA and zinc interact with genes of inflammation and immunity [57,58]. Whether the risk for AMD may be modified by interactions of PUFA and zinc with the CFH gene remains to be determined. Zinc has recently been implicated in the binding of $\mathrm{CFH}$ with its target complement factor (C3b) [59]. In the field of carotenoids, Pi isoform of the glutathione S-transferase (GSTP1) has recently been identified as a membrane-bound binding protein for zeaxanthin in the macula [60]. The same authors have shown that GSTP1 and zeaxanthin act in synergy for the prevention of membrane lipid peroxidation [61]. Interestingly, GSTP1 polymorphism was associated with the risk of cortical cataract in an Estonian population [62]. These data globally suggest that interaction of the GSTP1 gene with dietary zeaxanthin may be implicated in AMD and cataract.

In conclusion, age-related eye diseases, which are the major causes of blindness worldwide, are strongly influenced by nutrition and genetics. Nutrigenomics, by studying the interactions of nutritional and genetic factors, opens a new research avenue. Understanding the interaction 
of nutrients with genes may help target susceptible individuals for nutritional prevention of eye diseases.

\section{REFERENCES}

1. Resnikoff S, Pascolini D, Etya'ale D, Kocur I, Pararajasegaram R, Pokharel GP, Mariotti SP: Global data on visual impairment in the year 2002. Bull World Health Organ 2004;82:844-851.

2. Beatty S, Koh H, Phil M, Henson D, Boulton M: The role of oxidative stress in the pathogenesis of age-related macular degeneration. Surv. Ophthalmol. 2000;45:115134.

3. Boscia F, Grattagliano I, Vendemiale G, Micelli Ferrari T, Altomare E: Protein oxidation and lens opacity in humans. Invest. Ophthalmol. Vis. Sci. 2000;41:24612465 .

4. Delcourt C, Cristol JP, Tessier F, Leger CL, Descomps B, Papoz L: Age-related macular degeneration and antioxidant status in the POLA study. POLA Study Group. Pathologies Oculaires Liees a l'Age. Arch Ophthalmol 1999;117:1384-1390.

5. A randomized, placebo-controlled, clinical trial of high-dose supplementation with vitamins $\mathrm{C}$ and $\mathrm{E}$, beta carotene, and zinc for age-related macular degeneration and vision loss: AREDS report no. 8. Arch Ophthalmol 2001;119:1417-1436.

6. Taylor A, Hobbs M: 2001 assessment of nutritional influences on risk for cataract. Nutrition. 2001;17:845-857.

7. AREDS: A randomized, placebo-controlled, clinical trial of high-dose supplementation with vitamins $\mathrm{C}$ and $\mathrm{E}$ and beta carotene for age-related cataract and vision loss: AREDS report no. 9. Arch. Ophthalmol. 2001;119:1439-1452. 
8. McNeil JJ, Robman L, Tikellis G, Sinclair MI, McCarty CA, Taylor HR: Vitamin E supplementation and cataract: randomized controlled trial. Ophthalmology. $2004 ; 111: 75-84$

9. Teikari JM, Virtamo J, Rautalahti M, Palmgren J, Liesto K, Heinonen OP: Long-term supplementation with alpha-tocopherol and beta-carotene and age-related cataract. Acta. Ophthalmol. Scand. 1997;75:634-640.

10. Chylack Lt JR, Brown NP, Bron A, Hurst M, Kopcke W, Thien U, Schalch W: The Roche European American Cataract Trial (REACT): a randomized clinical trial to investigate the efficacy of an oral antioxidant micronutrient mixture to slow progression of age-related cataract. Ophthalmic. Epidemiol. 2002;9:49-80.

11. Schalch W, Dayhaw-Barker P, Barker FM: The carotenoids of the human retina. in Taylor A (ed): Nutritional and environmental influences of the eye. Boca Raton (USA): CRC Press, 1999, 215-250.

12. Yeum KJ, Shang FM, Schalch WM, Russell RM, Taylor A: Fat-soluble nutrient concentrations in different layers of human cataractous lens. Curr. Eye. Res. 1999;19:502-505.

13. Beatty S, Murray IJ, Henson DB, Carden D, Koh H, Boulton ME: Macular pigment and risk for age-related macular degeneration in subjects from a Northern European population. Invest. Ophthalmol. Vis. Sci. 2001;42:439-446.

14. Bone RA, Landrum JT, Mayne ST, Gomez CM, Tibor SE, Twaroska EE: Macular pigment in donor eyes with and without AMD: a case-control study. Invest. Ophthalmol. Vis. Sci. 2001;42:235-240.

15. Antioxidant status and neovascular age-related macular degeneration. Eye Disease Case-Control Study Group. Arch Ophthalmol 1993;111:104-109. 
16. Seddon JM, Ajani UA, Sperduto RD, Hiller R, Blair N, Burton TC, Farber MD, Gragoudas ES, Haller J, Miller DT, et al.: Dietary carotenoids, vitamins A, C, and E, and advanced age-related macular degeneration. Eye Disease Case-Control Study Group. JAMA 1994;272:1413-1420.

17. Snellen EL, Verbeek AL, Van Den Hoogen GW, Cruysberg JR, Hoyng CB: Neovascular age-related macular degeneration and its relationship to antioxidant intake. Acta. Ophthalmol. Scand. 2002;80:368-371.

18. Gale CR, Hall NF, Phillips DI, Martyn CN: Lutein and zeaxanthin status and risk of age-related macular degeneration. Invest. Ophthalmol. Vis. Sci. 2003;44:2461-2465.

19. Chasan-Taber L, Willett WC, Seddon JM, Stampfer MJ, Rosner B, Colditz GA, Speizer FE, Hankinson SE: A prospective study of carotenoid and vitamin A intakes and risk of cataract extraction in US women. Am J Clin Nutr 1999;70:509-516.

20. Brown L, Rimm EB, Seddon JM, Giovannucci EL, Chasan-Taber L, Spiegelman D, Willett WC, Hankinson SE: A prospective study of carotenoid intake and risk of cataract extraction in US men. Am J Clin Nutr 1999;70:517-524.

21. Lyle BJ, Mares-Perlman JA, Klein BE, Klein R, Greger JL: Antioxidant intake and risk of incident age-related nuclear cataracts in the Beaver Dam Eye Study. Am J Epidemiol 1999;149:801-809.

22. Jacques PF, Chylack Lt JR, Hankinson SE, Khu PM, Rogers G, Friend J, Tung W, Wolfe JK, Padhye N, Willett WC, Taylor A: Long-term nutrient intake and early agerelated nuclear lens opacities. Arch. Ophthalmol. 2001;119:1009-1019.

23. Richer S, Stiles W, Statkute L, Pulido J, Frankowski J, Rudy D, Pei K, Tsipursky M, Nyland J: Double-masked, placebo-controlled, randomized trial of lutein and antioxidant supplementation in the intervention of atrophic age-related macular 
degeneration: the Veterans LAST study (Lutein Antioxidant Supplementation Trial). Optometry. 2004;75:216-230.

24. SanGiovanni JP, Chew EY: The role of omega-3 long-chain polyunsaturated fatty acids in health and disease of the retina. Prog Retin Eye Res 2005;24:87-138.

25. Smith W, Mitchell P, Leeder SR: Dietary fat and fish intake and age-related maculopathy. Arch Ophthalmol 2000;118:401-404.

26. Heuberger RA, Mares Perlman JA, Klein R, Klein BE, Millen AE, Palta M: Relationship of dietary fat to age-related maculopathy in the Third National Health and Nutrition Examination Survey. Arch. Ophthalmol. 2001;119:1833-1838.

27. Seddon JM, Rosner B, Sperduto RD, Yannuzzi L, Haller JA, Blair NP, Willett W: Dietary fat and risk for advanced age-related macular degeneration. Arch Ophthalmol 2001;119:1191-1199.

28. Cho E, Hung S, Willett WC, Spiegelman D, Rimm EB, Seddon JM, Colditz GA, Hankinson SE: Prospective study of dietary fat and the risk of age-related macular degeneration. Am J Clin Nutr 2001;73:209-218.

29. Seddon JM, Cote J, Rosner B: Progression of age-related macular degeneration: association with dietary fat, transunsaturated fat, nuts, and fish intake. Arch Ophthalmol 2003;121:1728-1737.

30. Kang JH, Pasquale LR, Willett WC, Rosner BA, Egan KM, Faberowski N, Hankinson SE: Dietary fat consumption and primary open-angle glaucoma. Am. J. Clin. Nutr. 2004;79:755-764.

31. Miljanovic B, Trivedi KA, Dana MR, Gilbard JP, Buring JE, Schaumberg DA: Relation between dietary n-3 and n-6 fatty acids and clinically diagnosed dry eye syndrome in women. Am J Clin Nutr 2005;82:887-893. 
32. Gorin MB, Breitner JC, De Jong PT, Hageman GS, Klaver CC, Kuehn MH, Seddon JM: The genetics of age-related macular degeneration. Mol. Vis. 1999;5:29.

33. Congdon N, Broman KW, Lai H, Munoz B, Bowie H, Gilbert D, Wojciechowski R, West SK: Cortical, but not posterior subcapsular, cataract shows significant familial aggregation in an older population after adjustment for possible shared environmental factors. Ophthalmology. 2005;112:73-77.

34. Congdon N, Broman KW, Lai H, Munoz B, Bowie H, Gilber D, Wojciechowski R, Alston C, West SK: Nuclear cataract shows significant familial aggregation in an older population after adjustment for possible shared environmental factors. Invest. Ophthalmol. Vis. Sci. 2004;45:2182-2186.

35. Hammond CJ, Duncan DD, Snieder H, De Lange M, West SK, Spector TD, Gilbert CE: The heritability of age-related cortical cataract: the twin eye study. Invest. Ophthalmol. Vis. Sci. 2001;42:601-605.

36. Hammond CJ, Snieder H, Spector TD, Gilbert CE: Genetic and environmental factors in age-related nuclear cataracts in monozygotic and dizygotic twins. N. Engl. J. Med. 2000;342:1786-1790.

37. Seddon JM, Cote J, Page WF, Aggen SH, Neale MC: The US twin study of agerelated macular degeneration: relative roles of genetic and environmental influences. Arch. Ophthalmol. 2005;123:321-327.

38. Souied EH, Benlian P, Amouyel P, Feingold J, Lagarde JP, Munnich A, Kaplan J, Coscas G, Soubrane G: The epsilon 4 allele of the apolipoprotein E gene as a potential protective factor for exudative age-related macular degeneration. Am. J. Ophthalmol. 1998;125:353-359. 
39. Klaver CCW, Kliffen M, Vanduijn CM, Hofman A, Cruts M, Grobbee DE, Vanbroeckhoven C, Dejong PTVM: Genetic association of apolipoprotein E with agerelated macular degeneration. Am. J. Hum. Genet. 1998;63:200-206.

40. Simonelli F, Margaglione M, Testa F, Cappucci G, Manitto MP, Brancato R, Rinaldi E: Apolipoprotein E polymorphisms in age-related macular degeneration in an Italian population. Ophthalmic. Res. 2001;33:325-328.

41. Schmidt S, Klaver C, Saunders A, Postel E, De La Paz M, Agarwal A, Small K, Udar N, Ong J, Chalukya M, Nesburn A, Kenney C, Domurath R, Hogan M, Mah T, Conley Y, Ferrell R, Weeks D, De Jong P, Van Duijn C, Haines J, Pericak Vance M, Gorin M: A pooled case-control study of the apolipoprotein E (APOE) gene in agerelated maculopathy. Ophthalmic. Genet. 2002;23:209-223.

42. Zareparsi S, Reddick AC, Branham KE, Moore KB, Jessup L, Thoms S, Smith Wheelock M, Yashar BM, Swaroop A: Association of apolipoprotein E alleles with susceptibility to age-related macular degeneration in a large cohort from a single center. Invest. Ophthalmol. Vis. Sci. 2004;45:1306-1310.

43. Baird PN, Guida E, Chu DT, Vu HT, Guymer RH: The epsilon2 and epsilon4 alleles of the apolipoprotein gene are associated with age-related macular degeneration. Invest. Ophthalmol. Vis. Sci. 2004;45:1311-1315.

44. Klein RJ, Zeiss C, Chew EY, Tsai JY, Sackler RS, Haynes C, Henning AK, Sangiovanni JP, Mane SM, Mayne ST, Bracken MB, Ferris FL, Ott J, Barnstable C, Hoh J: Complement factor $\mathrm{H}$ polymorphism in age-related macular degeneration. Science. 2005;308:385-389.

45. Haines JL, Hauser MA, Schmidt S, Scott WK, Olson LM, Gallins P, Spencer KL, Kwan SY, Noureddine M, Gilbert JR, Schnetz Boutaud N, Agarwal A, Postel EA, 
Pericak Vance MA: Complement factor $\mathrm{H}$ variant increases the risk of age-related macular degeneration. Science. 2005;308:419-421.

46. Edwards AO, Ritter R RD, Abel KJ, Manning A, Panhuysen C, Farrer LA: Complement factor $\mathrm{H}$ polymorphism and age-related macular degeneration. Science. 2005;308:421-424.

47. Conley YP, Thalamuthu A, Jakobsdottir J, Weeks DE, Mah T, Ferrell RE, Gorin MB: Candidate gene analysis suggests a role for fatty acid biosynthesis and regulation of the complement system in the etiology of age-related maculopathy. Hum Mol Genet 2005;14:1991-2002.

48. Zareparsi S, Branham KE, Li M, Shah S, Klein RJ, Ott J, Hoh J, Abecasis GR, Swaroop A: Strong association of the $\mathrm{Y} 402 \mathrm{H}$ variant in complement factor $\mathrm{H}$ at $1 \mathrm{q} 32$ with susceptibility to age-related macular degeneration. Am J Hum Genet 2005;77:149-153.

49. Hageman GS, Anderson DH, Johnson LV, Hancox LS, Taiber AJ, Hardisty LI, Hageman JL, Stockman HA, Borchardt JD, Gehrs KM, Smith RJ, Silvestri G, Russell SR, Klaver CC, Barbazetto I, Chang S, Yannuzzi LA, Barile GR, Merriam JC, Smith RT, Olsh AK, Bergeron J, Zernant J, Merriam JE, Gold B, Dean M, Allikmets R: A common haplotype in the complement regulatory gene factor $\mathrm{H}(\mathrm{HF} 1 / \mathrm{CFH})$ predisposes individuals to age-related macular degeneration. Proc Natl Acad Sci U S A $2005 ; 102: 7227-7232$.

50. Souied EH, Leveziel N, Richard F, Dragon-Durey MA, Coscas G, Soubrane G, Benlian P, Fremeaux-Bacchi V: Y402H complement factor $\mathrm{H}$ polymorphism associated with exudative age-related macular degeneration in the French population. Mol Vis 2005;11:1135-1140. 
51. Magnusson KP, Duan S, Sigurdsson H, Petursson H, Yang Z, Zhao Y, Bernstein PS, Ge J, Jonasson F, Stefansson E, Helgadottir G, Zabriskie NA, Jonsson T, Bjornsson A, Thorlacius T, Jonsson PV, Thorleifsson G, Kong A, Stefansson H, Zhang K, Stefansson K, Gulcher JR: CFH Y402H Confers Similar Risk of Soft Drusen and Both Forms of Advanced AMD. PLoS Med 2005;3:e5.

52. Rodriguez de Cordoba S, Esparza-Gordillo J, Goicoechea de Jorge E, Lopez-Trascasa M, Sanchez-Corral P: The human complement factor $\mathrm{H}$ : functional roles, genetic variations and disease associations. Mol Immunol 2004;41:355-367.

53. Anderson DH, Mullins RF, Hageman GS, Johnson LV: A role for local inflammation in the formation of drusen in the aging eye. Am. J. Ophthalmol. 2002;134:411-431.

54. Fisher SA, Abecasis GR, Yashar BM, Zareparsi S, Swaroop A, Iyengar SK, Klein BE, Klein R, Lee KE, Majewski J, Schultz DW, Klein ML, Seddon JM, Santangelo SL, Weeks DE, Conley YP, Mah TS, Schmidt S, Haines JL, Pericak-Vance MA, Gorin MB, Schulz HL, Pardi F, Lewis CM, Weber BH: Meta-analysis of genome scans of age-related macular degeneration. Hum Mol Genet 2005;14:2257-2264.

55. Iyengar SK, Klein BE, Klein R, Jun G, Schick JH, Millard C, Liptak R, Russo K, Lee KE, Elston RC: Identification of a major locus for age-related cortical cataract on chromosome 6p12-q12 in the Beaver Dam Eye Study. Proc. Natl. Acad. Sci. U. S. A. 2004;101:14485-14490.

56. Malek G, Johnson LV, Mace BE, Saloupis P, Schmechel DE, Rickman DW, Toth CA, Sullivan PM, Rickman CB: Apolipoprotein E allele-dependent pathogenesis: a model for age-related retinal degeneration. Proc Natl Acad Sci U S A 2005;102:1190011905.

57. Calder PC, Grimble RF: Polyunsaturated fatty acids, inflammation and immunity. Eur J Clin Nutr 2002;56 Suppl 3:S14-19. 
58. Calder PC, Kew S: The immune system: a target for functional foods? Br J Nutr 2002;88 Suppl 2:S165-177.

59. Blom AM, Kask L, Ramesh B, Hillarp A: Effects of zinc on factor I cofactor activity of C4b-binding protein and factor H. Arch Biochem Biophys 2003;418:108-118.

60. Bhosale P, Larson AJ, Frederick JM, Southwick K, Thulin CD, Bernstein PS: Identification and characterization of a $\mathrm{Pi}$ isoform of glutathione S-transferase (GSTP1) as a zeaxanthin-binding protein in the macula of the human eye. J Biol Chem 2004;279:49447-49454.

61. Bhosale P, Bernstein PS: Synergistic effects of zeaxanthin and its binding protein in the prevention of lipid membrane oxidation. Biochim Biophys Acta 2005;1740:116121.

62. Juronen E, Tasa G, Veromann S, Parts L, Tiidla A, Pulges R, Panov A, Soovere L, Koka K, Mikelsaar AV: Polymorphic glutathione S-transferases as genetic risk factors for senile cortical cataract in Estonians. Invest. Ophthalmol. Vis. Sci. 2000;41:22622267. 